\title{
Sciendo
}

DOI: $10.2478 /$ jolace-2019-0008

\section{Gendered Performance, Fluid Identities and Protest in Tess Onwueme's Then She Said It}

\author{
Rowland Chukwuemeka Amaefula \\ Alex Ekwueme Federal University, Nigeria \\ emy4real2004@gmail.com
}

\begin{abstract}
This study examines the social constructions of gender as the encapsulation of reiterated human conducts within varying sites of performance. Contrary to the notion that gender roles are fixed by socio-cultural forces, this paper focuses on the fluidity of human dispositions in differing circumstances. Adopting Judith Butler's theory of gender performativity, the researcher analyses Tess Onwueme's Then She Said It. This protest play attests to the variability of gender performance. The characters in the drama, especially the protagonists and antagonists, exhibit considerable alterations in gender performance in different situations. Thus, the study argues that the rigid classification of gender roles along sex lines (on both biological and gendered sexuality) in protest drama in Nigeria is incongruous with the characters' dispositions in the plays. Indeed, characters adopt crossgendered performances as a strategy of protesting against overbearing conditions.

Key words: drama, protest, gender, sex, performance

\section{Introduction}

The beginning of women's accomplishment of heroism through protests is traceable to the renowned amazons of the classical Greek society. It is paradoxical to refer to this source given that the ancient Greek society upheld standards that lionised men and denigrated women. Christina Clark was right when she noted that the "Classical Greek culture was strongly marked by gender segregation. Generally, the public sphere was associated with men, the domestic, with women" (2009, p. 6). Unlike the Classical Greek females, some women in ancient Africa such as Queen Amina - a warrior, authoritative queen mothers, among other outstanding women leaders, "accomplished great feats; displayed exceptional skills and talents; stood up against oppression and injustice; and contributed much to the society" (Salami-Agunloye, 2006, p. 99). However, the advent of colonialism stifled the voice of women and entrenched a gender-oriented control mechanism that perseveres despite decolonization. The event of colonialism informs the (re)constructions of gender roles in protest drama in postcolonial Nigeria.
\end{abstract}


The protest drama genre in postcolonial Nigeria, according to Asigbo, was a reaction to "the impunity with which the military ruled the country hence writers [... of protest plays] incited the masses to be awake to their rights" $(2013$, p. 21). This category of drama was written by young dramatists who examine social problems in plays, arguing that the problems of Nigerians and indeed humanity are self-made and "not from the metaphysical realm or from the gods" (Obafemi, n.d., p. 46). Mainly written by such second generation of playwrights as Femi Osofisan, Bode Sowande, Emeka Nwabueze, Esiaba Irobi, Tunde Fatunde, among others, protest drama presents revolt as a panacea to socio-political problems that bedevil Nigerians. Beginning from the 1990s however, protest plays in Nigeria have been dominated with feminist messages, popularising the perspective that women are subordinated to men, and must revolt against the latter to attain gender parity.

John-Pepper Clark, in The Wives' Revolt, foregrounds protest in forestalling oppression against women. In 'Proclamation' for example, Okoro, the arrowhead of men's dictatorship in Erhuwaren community - the setting of the play, announces a sharing formula for money donated to the village by an oil company, and new policies that emasculate women's income. This declaration reinforces the prevailing thought that men are leaders; women, their passive subjects. Through self-exile therefore, the women of Erhuwaren protest against the decisions of men. The protest culminates in a reversal in gender performance: the hitherto dictatorial men become conciliatory and thus consent to the women's demands for a repeal of the proclamations. Evidently, without protest, women - whose socially assigned dispositions include passivity, docility and submissiveness - would infinitely be victims of men's excesses, especially in the promulgation of policies.

In fictionalizing the taxation policy and Aba Women's riot of 1929 in his play The Dragon's Funeral, Emeka Nwabueze projects women's protest in drama as not only a panacea for problems that affect them but also a determinant of gender performance and changing identities (2005). The female characters in the play form a women's league and embark on a riot, as a means of annulling the new taxation policy imposed on them. Although unprecedented, the women's resort to a riot proves to be the only power they wield in the intensely sexist Osisioma community - the setting of the play, since men occupy most positions of authority in the land. The women's protest yields fruits when colonial masters and their black collaborators fail to quell the revolt. Consequently, the famed strength of men - the colonial administrators and their warrant chiefs - is soon weakened in the face of women's protest, thereby seemingly validating the belief that men's prowess is dependent on women. This calls into question the rigidity of gender 
roles assignment in Nigerian drama, according to normative masculinity and femininity.

Based on the foregoing, this study examines gender roles in Tess Onwueme's Then She Said It vis-à-vis the characters' changing conditions. Clearly, the play to be examined here reveals a multiplicity of dispositions for women, culminating in conflicting gender roles. The dramatist foregrounds a multi-focal thrust, indeed, she interrogates an ambivalent sociocultural backdrop that presents women simultaneously as strong and spineless. In a number of post-independence Nigerian plays, women are presented as fearless, brave and bold or docile, submissive and seductive. For example, "The portrait of women as vile creatures in My Daughter is an Egg by Stella Oyedepo which sharply negates their image as worthy leaders in The Rebellion of the Bumpy-Chested by the same playwright," exemplifies conflicting gender roles (Rowland Amaefula, 2016, p. 2).

Nelly Furman notes that, in a sexist society such as Nigeria, "the trouble with woman is that she is at once an object of desire and an object of exchange, valued on one hand as a person in her own right and, on the other, considered simply as a relational sign between..." (1980, p. 51). The point being made here is that while gender roles for men in Nigerian protest drama are predicated on a culturallyconstructed gender imbalance that privileges men and subordinates women, the resulting construct is not fixed, it is fluid and open-ended. Thus, using Onwueme's Then She Said It as a model, this essay examines the nexus between protests in Nigerian drama and the shifting gender roles for men and especially women. Textual analyses are based on Judith Butler's Gender Performativity which emphasizes reiterations of role performances by an individual as a pathway to establishing his/her gendered identity.

According to Butler, "the gendered body utilizes semiotic and material signs (words, acts, gestures, and desire) to similarly create what appears to be an interiority", which she calls "the effect of an internal core on the substance" (2013). Butler further posits that

gender is stabilized by the construction of a norm - heterosexuality - against which all other gender constructions are measured and found wanting. This norm may be stabilized, but it is not fixed. It constantly needs to be re-performed since it is constituted by its 'acts', not by some essentiality (2013).

Such repeated performance indicates that gender exists momentarily, in process, instead of being a permanent fixture. In other words, one's gender performance cannot be determined at one time. It is recurrent and dynamic, depending on circumstances. A very quiet and submissive woman, when exploited to the point of provocation, could realize her condition and become 'aggressive', 
'bold' and 'ambitious' - attributes normatively ascribed to men, exclusively. This implies that the performance of gender is not only repetitive and fluid, performance can be used to both reinforce as well as contest gender constructs. Hence, Butler likens gender to style: "Gender is a style, rather than a substance, and styles are subject to change - they are fundamentally unstable, in need of further theatrical performance and public consensus concerning their importance" (2007; my emphasis). In Butler's gender performativity, public consensus is strengthened through repeated performance of gender roles in the presence of people. Thus, the difference between performance and performativity approximates the distinction between drag and gender. Notably, Butler discussed gender performativity in relation to drag. Drag indicates a mimetic representation of a particular gender category. It is a transient, situational act; a performance. However, performativity suggests "a continual resignification of gender" (Jenkins \& Finneman, 2017, p. 159). The point being made here is that gender identity is attained through the consistent reiteration of a specific gender performance. Any shift in gender performance however - possibly propelled by an overwhelming influence of a circumstance - deinstitutes the existing identity of the subject.

\section{A Deconstruction of Feminism, Gender and Sex}

Scholarly discourses on gender are often linked with feminism. The difference between both concepts lies in the level of their accommodation of both sexes. While gender considers the behavioural patterns associated with the male and the female, feminism, according to Lois Tyson, "seeks to understand the ways in which women are oppressed - socially, economically, politically and psychologically - in order to reduce, if not eliminate their oppression" (2011, p. 139). Feminism is mostly woman-specific while gender is not. Ideally, feminism in Nigeria presupposes that men are privileged over women in societies where patriarchy is prevalent and enshrined within the social fabric of societies, and this stimulates the need for the eradication of all systemic frameworks that inhibit woman from achieving her full potential. One of such inhibitions is ignorance.

This is evident in Ola Rotimi's Our Husband Has Gone Mad Again which presents Mama Rashida and Sikira as basically ignorant and, consequently, voiceless and powerless. Satisfied in subservience, they do not comprehend Lejoka-Brown's exploitative missions. With the entry of Liza however, Sikira and Mama Rashida realise the artificial foundation on which Lejoka-Brown builds their union, to fortify his patriarchal domination of them. Indeed, feminism encourages men and women to accomplish their goals, regardless of the traditional prescriptions of masculinity and femininity. 
Simone de Beauvoir argues that the notions of masculinity and femininity are social constructs that are designed to enslave woman (1952, p. 122). She states that all the creation myths evolved by men have affirmed female subservience: "Genesis tells us that woman was not created as a being in her own self but as a being for man... she was created to rescue man from loneliness... she was not created of the same dust as man but from man's ribs" (De Beauvoir, 1952, p. 88). Therefore, man's existence is a right woven in independence while woman's is an accident subordinated to man. De Beauvoir's arguments are pivoted on the idea that gender construction is patriarchy-based. Thus, she submits that, "One is not born a woman; one becomes one" (1952, p. 88). In reinforcing this point, Tyson argues that „...women wear pointy shoes with high heels not because they have pointy feet and need help reaching the top shelf of the cupboard, but because patriarchy tells them that such footwear is feminine. And such footwear is considered feminine because, among other things, it makes women less mobile and therefore, in appearance at least, less able to compete [with men]" (2011, p. 143).

Kate Millet likens gender to "a power-structured relationship and arrangement whereby (man) controls (woman)" (2007, p. 123). "Gender", Millet explains, "is a term that has psychological or cultural meaning rather than biological connotations... Gender role is determined by post-natal forces, regardless of the genitalia" (2007, p. 148). Thus, while sex is a biological manifestation, gender is culturally determined. The political implications of the social construction of gender categories become manifest when contemplated against the background of the socialization process. According to Millet, if man is the head of the family and "family is the chief agent of patriarchy," then the child receives his gender prescriptions through socialization, under the strict supervision of man (2007, p. 146). Millet further argues that among the features and conditions that define feminine and masculine genders are temperament, role and status:

\begin{tabular}{|l|l|}
\hline Women & Men \\
\hline $\begin{array}{l}\text { Temperament: passive, ignorant, } \\
\text { docile, ineffectual and virtuous. }\end{array}$ & $\begin{array}{l}\text { Intelligent, aggressive, force and } \\
\text { efficacy. }\end{array}$ \\
\hline $\begin{array}{l}\text { Sex Role: domestic chores and caring } \\
\text { for infants. }\end{array}$ & $\begin{array}{l}\text { Strenuous activities, the rest of human } \\
\text { achievements, interest and ambition. }\end{array}$ \\
\hline $\begin{array}{l}\text { Status: It follows that women will be } \\
\text { accorded a low status. }\end{array}$ & $\begin{array}{l}\text { It follows that men would be accorded } \\
\text { a high status. }\end{array}$ \\
\hline
\end{tabular}

(The table above was culled from page 146 of Kate Millet's article titled, "Sexual Politics.") 
The belief that gender roles are assigned according to an individual's sex is critically tenuous. It is widely accepted that sex is constructed on the plank of biological determinism (Christine Delphy, 1993, p. 3; Ann Oakley, 1985, p. 16). However, the conferment of high or low status on a sex regardless of the individual's level of achievements or manifest endowments, is questionable. Gender is a variable feature, not a rigid measurement of high or low status, as neatly laid out in the binary opposites contained in the table above. Oakley implicates gender in every recognized difference - social, psychological or cultural - between man and woman. These differences are observable overtime, and do not compulsorily take the shape of a laid down template that pre-exists an individual. In this regard, she states that, "The constancy of sex must be admitted, but so too must the variability of gender" (Oakley, 1985, p. 16). The variations in gender are therefore dependent on the dynamism of one's behaviour, performance or role.

Writing on gender and roles, Delphy notes that, "The notion of gender developed from that of sex roles, and, rightly or wrongly, the person who is credited with being the mother of this line of thought is Margaret Mead" (1993, p. 1). Delphy further remarks that, although Margaret Mead is only interested in examining "the feminine and masculine temperaments", her research motivated thoughts on sex roles, beginning from the 1940s to the 1960s" (1993, p. 2). The term 'role' is associated with performance. On the rehearsal floor of a theatre production, role technically connotes the acquisition of characterization; an activity. Delphy thus defines "a role as the active aspect of a status" (1993, p. 2). A status is a normative quality that prescribes roles and the concomitant pressure to perform them as a method of maintaining the class or status. Therefore, role performance can do a number of things; from restoring and reinforcing constructed stereotypes and beliefs, to resisting, challenging and negating the conditions of a status. If sex is a normative and constant status, then what is more? Gender is a variable, shaped by role performance.

Butler's position however runs counter to the constancy of sex. She theorises that 'The category of 'sex' is, from the start, normative; it is what Foucault has called a 'regulatory ideal'. In this sense, then, 'sex' not only functions as a norm, but is part of a regulatory practice that produces the bodies it governs, that is, whose regulatory force is made clear as a kind of productive power, the power to produce - demarcate, circulate, differentiate - the bodies it controls. Thus, 'sex' is a regulatory ideal whose materialization is compelled, and this materialization takes place (or fails to take place) through certain highly regulated practices" (1993, p. 12).

In other words, sex, in Butler's opinion, is a construct which is forcefully made manifest overtime. Its construction is achieved through reiterated enforcement of 
the norms that constitute it. The implication of this view is that, failure to enforce the regulatory law that sustains the construction of sex, the bodies might not comply with these norms by which its manifestation is compelled. Thus, sex is "not simply what one has or a static description of what one is: it will be one of the norms by which 'one' becomes viable at all, that which qualifies a body for life within the domain of cultural intelligibility" (Butler, 1993, p. 13).

According to this view, societal norms propel the construction of sex while gender appropriates the social significance of sex. Accordingly, the social institution of the natural supposes the de-institution of the natural by the social. The question then is, if gender is the social-cultural meaning and interpretation assigned to sex, what then is sex when it assumes the social character and significance of gender? If gender comprises the social importance of sex, then sex does not amass any social relevance but is instead displaced by its social value gender. Thus, "sex is relinquished in the course of that assumption, and gender emerges, not as a term in a continued relationship of opposition to sex, but as the term which absorbs and displaces sex" (Butler, 1993, p. 45). The point being made here is that sex is as much a social construct as gender.

The dynamism and flexibility associated with gender underscores the possibility of variegated masculinities and femininities. There is no iron-cast demarcation between gender roles but an individual's attributes-in-action determine his or her gender performance. According to Sara Mills and Louise Mullany, "Gender has progressed from being conceptualized as something which individuals have, an essential quality acquired through the socialization process, to something that individuals do/actively perform... gender is co-constructed within interactions" (2011, p. 41). In this light, Mills and Mullany's argument contests and contradicts the earlier notion that gender construction is a societal outline that pre-exists individuals; in effect, the patriarchy-driven construction has been supplanted with the view that "participants in conversation bring about their gendered identity, thus seeing gendering as a process of emergence, and one that is not completed" (2011, p. 41). Gender is a process, not a project. Therefore, it is increasingly obsolete to assume that men as a homogenous group unanimously oppress women as a homogenous group; that masculinity imbues men with feelings of superiority, and femininity plagues women with airs of inferiority. For instance, the isolation of characters along sex lines in Julie Okoh's Edewede confers their gender performance with overstretched homogeneity (2000). The depiction of men as collective tormentors of women in the play erodes individualised gender performances and renders old women - the supposed brainwashed collaborators of men - displaced. 
The strict delineation of characters' gender roles along sex lines disregards the prevalence of some women whose interiority is masculine and some men whose interiority is feminine; gays, lesbians, effeminate persons and other nonconventional forms of sexuality. Newton, qtd. in Butler, 2013 corroborates this stance when she argues that "At its most complex, (drag) is a double inversion that says, 'appearance is not reality...' my 'outside' appearance is feminine, but my essence 'inside' is masculine. At the same time, it symbolizes the opposite inversion; 'my appearance' outside (my body, my gender) is masculine but my essence 'inside' (myself) is feminine" (2013, p. 5).

Indeed, the performance and interactions of such individuals violate the notion of gender as socially prescribed conventions imposed on an individual. Mills and Mullany summarise this view as follows: "Researchers have moved away from a reliance on binary oppositions and global statements about the behaviour of all men and all women, to more detailed and mitigated statements about certain groups of women or men in particular circumstances, who reaffirm, negotiate with and challenge the parameters of permissible or socially sanctioned behaviour... Rather than seeing gender as a possession or set of behaviours which is imposed upon the individual by society...many feminists now...view gender as something which is enacted or performed, and thus a potential site of struggle over perceived restriction in roles... Thus, gender is not a given, but rather a process which one has to constantly perform" (2011, p. 42; emphasis added).

It is instructive to note that gender performance is the materialization of an individual's body through reiterations of (un)stable gendered behaviour in discourses. For example, in Clark's Song of a Goat, Ebiere's initial gender performance coheres with the feminine attributes of a wife (1977). However, the quest to prove her fecundity in the course of the dramatic actions, pushes her into an incestuous relationship with Tonye, the younger brother of her husband, Zifa. Ebiere's rebellion against a conventional family order is instigated by her disadvantaged position in the marriage and the desire to unmask Zifa's duplicity (Clark, 1977). Thus, her rebellion departs from and de-institutes her hitherto gender performance. This shift in gender performance strengthens the view that gender is a "potential site of struggle over perceived restriction in roles" (Mills and Mullany, 2011, p. 42). Indeed, the gender role of an individual is a circumstanceconditioned performance of his/her interiority.

\section{A Historical Survey of Protest in Nigeria Drama}

Within Protest Plays, one is confronted with a dual demonstration of rejection; first, at the level of gender identity, and second, with the nature of the drama. Protest Plays have been described as dramatic works that dwell on the varying 
layers of disillusionment Africans experience(d) at the hands of native postIndependence leaders (Saint Gbilekaa, 1997, p. vi). According to Alex Asigbo, "a major reason ... that shaped the writing of this period was the impunity with which the military ruled the country hence writers [... of protest plays] incited the masses to be awake to their rights" (2013, p. 21). In describing them as "emergent drama", Olu Obafemi notes that they are written by young dramatists who seek to "break down societal problems in the light of real historical occurrences" (n.d., p. 46). Continuing, Obafemi avers that Protest Plays present the argument that the problems of humanity are self-made and that they are "not from the metaphysical realm or from the gods" (n.d., p. 46).

The socio-political factors that led to protest drama in Nigeria are located in failure of leadership and the then emergent class consciousness which, according to Gbilekaa, resulted from the "...socio-political and economic developments after Nigeria's civil war and the replacement of cash crops like cocoa, groundnuts, palm oil and beniseed by petroleum, as the major item of export... [This] further widened the gap between the haves and have-nots, thus creating a class-conscious society. This brought a gradual thematic shift from the individual lone ranger to the masses of the society. The gloomy and bleak picture of the future characterized by the plays of Soyinka and Clark, the single history-making individual in the plays of Rotimi gave way to the masses' hero in the drama of the new generation of playwrights like Femi Osofisan, Kole Omotosho, Bode Sowande, Bode Osayin and many others" (1997, p. vi).

The import of Gbilekaa's postulation is that the disconnection of the masses from Agriculture - their familiar economic mainstay - pauperized them while the sales of crude oil catapulted a few others to the niche of affluence. Thus, protest drama was stimulated by the combination of the then emerging class consciousness and the crushing effects of inept leadership.

Commenting on the leadership woes in Nigeria's post-independence period, Chinua Achebe states that "The trouble with Nigeria is simply and squarely a failure of leadership. There is nothing basically wrong with the Nigerian character. There is nothing wrong with the Nigerian land or climate or water or air or anything else. The Nigerian problem is the unwillingness or inability of its leaders to rise to the responsibility, to the challenge of personal example which are the hallmarks of true leadership" (1983, p. 1).

Thus, playwrights of protest plays identify incompetent leadership as the major cause of the country's woes. Achebe, while citing James Booth, captures the prevailing mentality of politicians such as Awolowo, thus: "I was going to make myself formidable intellectually, morally invulnerable, to make all the money that 
is possible for a man with my brains and brawn to make in Nigeria" (Achebe, 1983, p. 14).

Undoubtedly, the mentality above was bound “...to produce aggressive millionaires than selfless leaders of their people" (Achebe, 1983, p. 14). Selfish leadership in the post-independence Nigeria did not only negate all the nationalists' pre-independence pledges but also pauperized the average Nigerian. As a panacea, playwrights of protest plays called for the overthrow of the current crop of leaders, using the theatre platform. Gbilekaa notes that "Besides challenging Aristotle's 'commandments', theatre since the advent of Marx and Engels has taken a definite ideological position in the on-going class struggle. In African theatre today, most Marxist analyses of the society have been employed both in conventional and popular theatre to release the people from the claws of, and even to urge them to revolt against, the decadent social order that oppresses them" (1997, p. i).

The excerpt above resonates the view that protest plays do not seek to endorse Nigeria's indigenous traditions but to address the leadership-induced quagmires of the country.

The adoption of the revolutionary model of playwriting has endured across successive periods. This is discernible in the playwrights' ideological commitment - their constant deployment of the revolutionary feature of theatre to conscientize the exploited populace. The playwright achieves this by creating social awareness and depicting insurgence against oppressive leaders in a manner that would induce imitation in real life circumstances. Thus, according to Obafemi, while the first generation of playwrights in Nigeria "deal with universal verities and metaphysical profundities such as the part-psychic search for the meaning of life and death in Soyinka's The Road," the second generation of playwrights such as Femi Osofisan, Bode Sowande, Emeka Nwabueze, Esiaba Irobi and Tunde Fatunde tackle urgent social problems that have immediate practical utility to mankind (n.d., p. 92).

It is noteworthy that beginning from the 1990s, Protest Plays in Nigeria have been dominated with feminist messages, entrenching the view that women are widely oppressed by men, and must revolt against the latter to erode gender-based subjugation.

\section{The Synopsis of Tess Onwueme's Then She Said It}

Then She Said It by Tess Onwueme is a graphic demonstration of the tussle of the Niger Delta people of Nigeria who live in penury in the midst of abundant natural resources. Set in Hungeria - a metaphor for the Niger Delta region of Nigeria - the play dramatizes the people's resoluteness to overcome the age-long 
exploitation of their region by the government at the centre - the federal government. The play begins with a prelude that showcases the suffering of the people - gunshots rattle a supposed peaceful environment as stray bullets disfigure old women, girls and even men. The people lament and decry the issues that bedevil their region: poverty, starvation, inadequate supply of fuel, water and electricity, rape, unemployment, state-sponsored terrorism and genocide, environmental pollution and betrayal. Amidst this lamentation, the people resolve to fight back until their plight draws international recognition. Different characters symbolise each of the issues interrogated in the play: Obida is a serial victim of betrayal and incestuous rape perpetrated by her uncle, Ethiope; Ethiope represents the ruling class in the Niger Delta region that persistently betray their people in order to amass wealth for themselves and gain more power and fame; Atlantic represents the multinational corporations that persistently seek more gains at the expense of the people; Oshun is a typical young lady of the Niger Delta region who resorts to prostitution as a means of survival; while Niger and Benue represent distraught mothers in the Niger Delta region who can neither provide for nor control/influence their children's upbringing and activities.

Onwueme's Then She Said It exposes the complicity of Hungerian leaders in the pauperization of the common man: foreign oil company operators such as Atlantic connives with the leaders to steal the country's oil wealth, and rewards the people with a pittance that is, in turn, stolen by greedy local chiefs such as Ethiope. As the exploitation of the Niger Delta people becomes unbearable, they jointly coordinate a mass protest and an attack against their exploiters - oil companies, local leaders and federal government. Pandemonium reigns awhile as the protesters defy law and order. The declaration of a State of Emergency introduces a new leader that freely uses state weapons and firepower on defenseless citizens thereby inflicting more personal pain and collective damage on the protesters than they (the protesters) caused. Having sacked many communities and apprehended a handful of the protesters, the new leader charges them to court. The new leader however is not different from the rulers he replaced. Thus, he compromises Trial Judge that will try the incarcerated protesters in court. By switching places with Trial Judge and Defence Lawyer, Obida and Koko respectively disguise themselves as the legal experts. This singular action of theirs overturns the earlier compromise made by the new leader and Trial Judge. Finally, a "No Guilty" is retuned when the arrested leaders are tried in an international court.

\section{The Historical Contexts of Then She Said It}

Then She Said It is set in the Niger Delta region of Nigeria in West Africa. In Niger Delta, women are often saddled with such economic responsibilities in the 
family as wives, mothers and breadwinners. Emmanuel Osewe Akubor substantiates this point when he states that "Niger Delta women... are the poorest in the world as a result of the oil production, which brought about environmental degradation and poverty and subsequent crisis" (2011, p. 27). Specifically, environmental degradation and exploitation of the ecosystem by the multinational companies in the region account for the worsening economic activities of the inhabitants of the Niger Delta region. This unstable socio-economic condition degrades and relegates the men to the position of constant job seekers and renders women vulnerable to rich and randy male expatriate workers. Indeed, each case of gas flaring, rape, damage of oil pipeline and other forms of hostilities in the region further weakens women's economic condition and fosters a militant disposition within them. Hence, unlike women in other regions in Nigeria, they actively participate in militant activities and demonstrations, protests and other forms of resistance captured in Tess Onwueme's Then She Said It.

The characters in the play bear the names of the major rivers in the Niger Delta region and beyond. For example, the character called Oji represents the South East wing of the Niger Delta region. Oji River is the name of a major river in Enugu State, South East, Nigeria. Oshun stands for the South West component of Niger Delta; Kainji is named after a dam built across River Niger in the Middle Belt region (North Central); while Benue signifies River Benue, a major river that runs from Cameroun and joins River Niger in Lokoja, Kogi State in Northern Nigeria. The playwright's adoption of names of the major rivers in different parts of the county is an implicit acknowledgement that the subject matter in Then She Said It is a national one. An international dimension to the problem is reflected in the choice of the character called Atlantic. He represents the Multinational Corporations that inflict hardship and poverty on the people of Niger Delta. True to his capitalist nature, Atlantic, in his insatiable quest for more gains, erodes joy from the region and constructs himself as a purveyor of pain and penury in Niger Delta.

Nationally and within the play, the local leadership of the Niger Delta region is compromised. The leaders like Atlantic and Ethiope in whom the people repose communal trust often volunteer themselves as accessories of exploitation of the area. Ethiope, in the play, represents compromised leadership. Apart from raping his niece, he also makes money by selling his female relatives as sex slaves to expatriate workers. Indeed, the Niger Delta region parades compromised leaders who aim at personal goals to the detriment of communal targets. It is against this backdrop that Onwueme, arguably the most prominent female playwright in Nigeria, evokes protest as a panacea for continued exploitation of women; and a core condition for contesting and de-stabilizing the principles and practices of rigid gender roles. 


\section{Gendered Performance, Fluid Identities and Protest in Then She Said It}

Generally, Onwueme's theatre parodies so-called official responses to cries against the exploitation and oppression of the downtrodden. Although Missing Face and Legacies border on attempts to trace one's roots, both plays do not erode the fact that Onwueme habitually launches a scathing criticism on mis-governance, tyranny and frivolous leadership without necessarily providing anti-dotes built on solid structures; her solutions are based primarily on the force of superior argument than on socio-culturally grounded interventions and practices. Her main strengths are initiating a debate between the marginalised and their oppressors and in which the former relies on the force of reason to both articulate their plight and to justify their actions. Iniobong Uko corroborates this view when she states that "Onwueme's writings find relevance within the framework of the theatrical practices of Bertolt Brecht" - which encourages the self-determination of a man's fate (2004, p. 189). This theme runs through most of Onwueme's plays. Therefore, if the attack on repressive leadership led by Wazobia, the heroine in The Reign of Wazobia, is confrontational, the women's protest in Then She Said It climaxes the theme of revolt in her plays.

Onwueme's Then She Said It is a graphic replay of the consequences of oil exploration on the flora and fauna of the Niger Delta region. The activities of oil companies result in the depletion of the ecosystem and corrosion of the people's traditional means of livelihood - fishing and farming. Thus, farmers are rendered redundant while educated young people seek employment opportunities in the oil companies, without success. The pathetic state of affairs in Hungeria - a metaphor for Nigeria - is revealed in the dialogue between Obida and Niger:

Niger: Poor child! So you teachers have also joined the tribe of unemployed, ehn?

Obida: They've killed everything with their oil pollution and spillage. We cannot breathe fresh air. Fishes die or get fried in the polluted simmering rivers. Waterwater everywhere. But we have no clean water to drink! And now we lose the land too?

Niger: No firewood because the plants and trees are soaked in oil. What do they expect us to cook with? (Onwueme, 2002, p. 14-15).

The dialogue above paints the picture of a pauperized people. Indeed, the Niger Delta region of Nigeria is an area blessed with vast natural resources, especially crude oil. However, the people are paradoxically poor, owing to sustained oil exploration activities by successive Nigerian leaders who hardly make corresponding efforts to enhance the living conditions of the residents. Thus, it is not surprising that the citizens of Hungeria take to crime while successive 
governments unleash military bombardments on the people, their homes, everything. To assert their humanity therefore, the people resort to protests.

Protest becomes a principal change factor in the gender performance of the characters in the play. Beginning from the Prologue, the fluidity of gender performance is made manifest. At first, women cower in fear over gunshots and heavy bombardments from the military.

Wounded and out of breath..., they continue to nurse and comfort the traumatized who still cry out loud: 'They took her... tore her up before me. See! See what they're doing to me at my old age!' an old woman cries out (Onwueme, 2002, p. 1).

This superfluous outpouring of emotions conveys the vulnerability of women. This portrait of women as fragile beings coheres with the traditional gender description of women as weak and defenseless. In traditional Nigerian societies, women are expected to be domestic, weak, naïve and acquiescing. Thus, the forgoing image of women in the play establishes their prevailing gender performance as dictated by the norms in the Niger Delta area of Nigeria.

However, the continuous bombardments and gunshots fail to break their spirit but soon transforms the women's apprehension into a collective will to protest. This is in tandem with the Butlerian postulation that "...subversion is precisely an incalculable effect. In fact, that's what makes it subversive" (2009). To destabilise an instituted gender performance of an individual is not an intentional activity influenced by choice. Subversion of gender performance is a consequence of an overwhelming condition, inspired by the subject's inability to maintain a gender identity created and repeated overtime in different sites of discourse.

The playwright captures the subversion process as follows:

For a while, thick shrouds of silence drape the land, until one by one, (the women) reemerge, angry, defiant, determined to be no longer crippled with fear and silence. With everyone gathering, soothing and holding on to the other, they slowly form a human chain until they break into songs of solidarity (Onwueme, 2002, p. 1; emphasis added).

Apparently, the hitherto gender performance of women as weak and pathetic preys of violence is swiftly transformed into that of defiant, rebellious purveyors of protests. The point being made here is that, beginning with protest over their conditions in the fashion Augusto Boal describes as rehearsals for revolution, the women develop militant traits that are traditionally considered masculine in Nigerian sociocultural settings. As evident in the instances of gender role transformation that inundates the play, the rigid demarcation between the normative gender performance of men and women, is blurred. This coheres with Butler's theory of performativity (as elaborated in Bodies that Matter) which defies categorical comprehensions of gender, proposing that gender is established (and 
re-established) through ritualized performances of gender norms. She also suggested prospects for subjects to subvert gender through de-instituting the instituted acts. The initial gendered behaviour of the women in Then She Said It is in consonance with Nigerian norms for femininity: feeble, gentle, placatory, seen but not heard.

In fact, in many parts of Nigeria, women's traditional gender roles are largely inferior to those of men. I. E. Nwosu reinforces this point as follows:

Historically, in the typical traditional African Society such as Nigeria, women are not only perceived as inferior to men but are marginalized and denied equal opportunities as the men, and women are treated as "lower gender" or "weaker sex"... the general belief is that the role of women start and end with running of the home and nothing more... women constitute the group at the bottom of the ladder in many developing countries, especially in Africa, in respect of employment, poverty, education, training and status (2012, p. 1240).

Drawing from the foregoing, it is apparent that the women's unconscious dereliction of their traditional gender performance in the play, illustrates Judith Butler's theory of performativity in terms of the fluid gender identity their actions generate.

Onwueme's Then She Said It presents gender as an unstable experience; its variability being dependent on the current conditions, not choice, of the characters. In 'Movement One', Oshun, the young daughter of Niger, is an object of male gaze who readily markets herself to Atlantic, an oil mogul. The stage direction and dialogue below describe her thus:

Her red short skirt, sleeveless blouse, which taunts the eyes, rudely announce her agile, youthful body mounted above platform shoes... Atlantic pulls her into his bosom, and sends his hand to work and wander around her willing body.

Atlantic: (To Oshun): Sweetie. More baby. More!

Oshun: To you. I'm at your service...

Atlantic: You belong to me, Babe.

Oshun: Now (Onwueme, 2002, p. 3).

Evidently, Oshun's gender performance here is in consonance with the orthodox gender performance of some women in Nigerian drama. She is not important to Atlantic beyond the gratification of his sexual desire. On the other hand, Oshun considers him only as a source of income. She confides in Obida that, “...We'll keep playing the fool to get what we want" (Onwueme, 2002, p. 11).

In reconciling this statement with the extant notion of femininity in Nigeria, it becomes obvious that Oshun's compliance with normative expectations of her gender category is psychologically precarious; she unconsciously admits that her gender role in relation to Atlantic's equals 'foolishness' but is further compelled by 
socioeconomic pressure to key in accordingly. Beyond the surface level, it can be inferred that the workings of her mind contradict her gender performance; her interiority is at variance with her exteriority. Her interior self, suppressed by overwhelming realities: crushing poverty and the desire to make money, assesses her current exteriority - gender performance - as foolish. However imprudent, Oshun necessarily keys into such gendered behaviour to sustain her gender identity and reinforce the trending mindset of many young Nigerian girls in her condition who believe that, 'a lady uses what she has to get what she wants'.

Commenting on the compelling influence of norms on gendering and sexing bodies, Butler states that peer pressure and allied societal norms constitute a practical problem in the society. For instance,

If you are in your late twenties or your early thirties and you can't get pregnant for biological reasons, or maybe you don't want to, for social reasons - whatever it is - you are struggling with a norm that is regulating your sex. It takes a pretty vigorous (and politically informed) community around you to alleviate the possible sense of failure, or loss, or impoverishment, or inadequacy - a collective struggle to rethink a dominant norm (1996, p. 113).

In keeping with the excerpt above, the growing quest to challenge all institutional oppressions combines with Oshun's eventual discovery of her exploited status to form the 'vigorous', 'politically informed', 'collective struggle' to rethink and dislodge a dominant norm. It is not surprising therefore that, in Movement Five when she eavesdrops on Atlantic's conversation with Chief Ethiope - the villagers' representative who trades his nieces to the white expatriates in exchange for wealth, the exploitative motives of Atlantic and his oil company dawn on her. Thus, she resolves to teach them a lesson. Expectedly, this realization occasions a change in her relationship with Atlantic in Movement Six:

Atlantic: I have you. Where do you think you're going?

Oshun: Home.

Atlantic: Why be in such a rush?

Oshun: It's time. Time. I'm done...

Atlantic: ...Why this sudden change...But haven't I been treating...taking care of you?

Oshun: That you have. But don't you think I can do it better for myself instead of having to depend... (Pause.) Anyway, I'm on my way now. Got to move on!

(Onwueme, 2002, p. 47-8).

This dialogue shows that Oshun's recognition of her subsidiary and subordinate relationship with Atlanta, leads to protest. Incensed by her realization of Atlantic's exploitative antics, Oshun discards her poverty-induced gender performance and, in consonance with Butler's theory on gender performativity, 
unconsciously exteriorizes her interiority: she becomes firm, assertive and decisive - gender attributes traditionally ascribed to masculinity.

In Onwueme's Then She Said It, the traditional character of masculinity is impulsively bestowed on female characters during protests. For instance, Obida, a serial rape victim, is empowered with demonstrable leadership qualities. Her defiance is a big shift in posture as she is transformed and endowed with defiant attitudes, in protest against an oppressive status quo. Cuklanz and Moorti posit that "This 'post-rape' narrative strategy permits the character to side-step" the harrowing consequences of rape (2011, p. 117). Obida's resoluteness thus proves that, instead of languishing in laments, a woman can also have a successful life after rape. Indeed, and according to Cuklanz and Moorti, "There is life after rape - that is, the raped woman is a survivor" (2011). Poised for protests therefore, Obida confronts the major forces of oppression in the play. Jeremiah S. S. Methuselah describes her as follows:

Obidah, who has clearly demonstrated leadership qualities, is however, undaunted. In spite of the clash she has with the police earlier on, the next time we see her, she is organizing the women and youth to protest in front of the GRA/Oil club (2010, p. 122).

Aside Oshun and Obida, women in the play resort to protest as a collective survival strategy and, in the process, challenge normative feminine gender performances, and acquire attributes that are traditionally defined as masculine. This makes gender a fluid and dynamic experience in the play.

Beyond the female characters, male characters in the play also undergo changes in their gender performance. Kainji, Oshun's lover, is passive in many fronts: he depends on Oshun for job and even protection. She describes him as her "handbag" with whom she travels. Evidently, Kainji's gender performance subordinates him to Oshun just as she is initially dependent on Atlantic. Kainji's gender performance contradicts the customary gendered behaviour of men Nigeria. The customary concept of masculinity in Nigeria prescribes resoluteness, ambition, assertiveness and domination. However, Kainji's eventual assumption of duty as Atlantic's guard suddenly lionises him, rendering him aggressive and proactive, in line with the traditional gender roles of men. This transformation demonstrates the Foucauldian principle upon which Butler builds her theory of gender performativity. "The Foucauldian premise", according to Butler, "stipulates that power works in part through discourse and it works in part to produce and destabilise subjects" (1996, p. 112). It can therefore be inferred that Kainji's new status as guard partly establishes a new subject for him, destabilising his former gender performance/identity. 
Similarly, Atlantic's penchant for threats, aggression and tyranny soon softens, and he becomes placid. His cowardice is most manifest when the women gear up for confrontation. The dialogue goes as follows:

Atlantic (Frightened.): They're already here?

Government Official: No, they're marching.

Atlantic (Alarmed.): Where?

Government Official: On the streets.

Atlantic: They're coming? (Sighs.) I'm finished. Hold me... finished. We're finished... (Onwueme, 2002, p. 98).

The hitherto aggressive Atlantic becomes completely emasculated when he is abducted by the 'women'. This singular act amplifies the idea of gender role reversal and confirms as well as reinforces Butler's notion of gender performativity, which discountenances the ascription of any permanent attribute to a particular sex, in the absence of repeated performances which institute and sustain it.

Akin to Atlantic's change in gender performance is Chief Ethiope's infantile reaction to his realization that the women have seized and disrobed the Trial Judge: Obida is dressed as the Trial Judge while Koko dons the outfit of the Defense Lawyer. Chief Ethiope is rendered powerless and weak. Swiftly, these new attributes destabilise his former gender performance and identity from ego-driven libidinous sexuality and licentiousness to that of cowardice and extreme anxiety. Recognising Koko and Obida, Atlantic and "The Chief (are) horrified by the sight of the scarified women before them... (and Chief) falls as he grips them both... The men are stupefied...)" (Onwueme, 2002, p. 115). This scenario marks the women's success in taking their ordeal to the global stage.

Onwueme's Then She Said It is a reinforcement of Butler's concept of performativity - whereas the enforcement of socio-cultural norms fix sex roles for men and women, gender identities are de-instituted by incalculable circumstances which combine to frustrate the sustenance of an already established gender performance. The change and manifestations of weakness, fear and anxiety in Chief Ethiope are extreme to the extent that no one would realize his former performed behaviour or even associate him with domestic and sexual abuse, rape, violence, immorality and insensitivity.

\section{Conclusion}

Tess Onwueme's Then She Said It projects protests against exploitations perpetrated by patriarchal society. In the play, protest is presented as not only a viable weapon in the fight against oppression and exploitation but also a major factor that determines the impulsive alteration of an individual's gendered 
dispositions. At first, the male characters are portrayed as exploitative, brutish and wicked while the female characters are characterised as passive victims of patriarchal sociocultural constructs and the former's brutality. These portrayals cohere with the conventional notion of gender roles in Nigeria. However, in the times of protest, both the male and female characters unconsciously cross the border of their gendered behaviour, and engage in role reversal - the female characters become aggressive and resistant while the male characters cease to be exploitative and plead for peace. Incidentally, few women in Nigerian drama are presented as exploitative due probably to the traditional notion of gender roles in the country - men occupy most positions of authority while women are almost shut out.

The strict demarcation of gender roles along biological lines 'de-realizes' the gender performance of men and women in the play under focus. Thus, the study establishes that circumstances constitute a major determinant for the sustenance or shift in an individual's gender performance. Examining Onwueme's Then She Said It against the backdrop of Judith Butler's theory of gender performativity, this paper concludes that gender performance is not culturally prescribed but conditionally determined. Being a temporal and performative experience, gender is fluid and unstable. The preoccupation of one's interiority together with current circumstances is a catalyst for one's gender performance; the performance being an exteriorization of the inner self. This explains why the characters in the plays, regardless of their sexes, exude attributes traditionally associated with men, in times of comfort and affluence, and reverse such gender performance in the face of opposition, danger and peril. 


\section{References}

Achebe, C. (1983). The Trouble with Nigeria. Enugu: Fourth Dimension.

Akubor, E. 0. (2011). The travail of women in the crises in the Niger Delta area. Anthropologist 13(1), 27-31.

Amaefula, R. C. (2016). Ideological commitment and portrait of women in the plays of Stella 'Dia Oyedepo. In Nwabueze, E. (Ed.), African Female Playwrights: A Study of Matter and Manner. Enugu: ABIC, pp. 258-275.

Aristophanes. (1984). Lysistrata. In: William A, Richmond A and Douglas P (Trans) Four Plays. New York: New American Library, pp. 342-460.

Asigbo, A. (2013). Fighting from the Trenches: Nigerian Playwright and the Task of Nation Building. Awka: UNIZIK press.

Butler, J. (1993). Bodies that Matter: On the Discursive Limits of Sex. New York, Routledge.

Butler, J. (2013). From interiority to gender performatives. In Richard J. L. (Ed.), Global Literary Theory: An Anthology. Oxon: Routledge, pp. 581-587.

Butler, J. (1996). Gender as performance. In Osborne. P. (Ed), A Critical Sense: Interviews with Intellectuals. New York: Routledge, pp.12-26.

Butler, J. (1999). Gender Trouble: Feminism and the Subversion of Identity. New York: Routledge.

Butler, J. (2007). Imitation and gender insubordination. In Gilbert, S. M. \& Guber, S. (Eds), Feminist Literary Theory and Criticism: A Norton Reader. New York: Norton, pp.708-722.

Butler, J. (2009). Performativity, precarity and sexual politics. AIBR. 4(3), i-xiii.

Butler, J. (2004). Undoing Gender. New York: Routledge.

Clark, C. A. (2009). To kneel or not to kneel: gendered nonverbal behaviour in Greek ritual. Women, Gender and Religion, 5, 6-20.

Clark, J. P. (1977). Song of a Goat. Ibadan: Ibadan University Press.

Clark, J. P. (1991). The Wives' Revolt. Ibadan: Ibadan UP.

Cuklanz, L. M. \& Moorti, S. (2011). Television's "new" feminism: prime-time representations of women and victimization. In Dines, G. \& Humez, J. M. (Eds), Gender, Race and Class in Media: A Critical Reader. California: SAGE, pp.560-589. De Beauvoir, S. (1952). The Second Sex. New York: Vantage Books.

Delphy, C. (1993). Rethinking sex and gender. Women's Studies Int. Forum 16(1), 1-9.

Foucault, M. (2013). Scientia sexualis. In Lane, R. J. (Ed.), Global Literary Theory: An Anthology. Oxon: Routledge, pp. 592-600.

Furman, N. (1980). Textual feminism. In MacConnell-Ginet, S. (Ed.). Women and Language in Literature and Society. New York: Praeger Publishers, pp.45-54. Gbilekaa, S. (1997). Radical Theatre in Nigeria. Ibadan: Caltop. 
Jenkins, J. (2017). Gender trouble in the workplace: applying Judith Butler's theory of performativity to news organizations. Feminist Media Studies 18(2), 157172.

Methuselah, J. S. S. (2010). Engendering women in Onwueme's drama: Then She Said It discussed. Creative Artist: A Journal of Theatre and Media Studies 4(1), 112-128.

Millet, K. (2007). Sexual politics. In Gilbert, S. M. \& Guber, S. (Eds.), Feminist Literary Theory and Criticism: A Norton Reader. New York: Norton, pp. 336350.

Mills, S. \& Mullany, L. (2011). Language, Gender and Feminism: Theory, Methodology and Practice. Oxon: Routledge.

Nwabueze, E. (2005). The Dragon's Funeral. Enugu: ABIC.

Nwosu, I. E. (2012). Gender role perceptions and the changing role of women in Nigeria. International Journal of Agric. And Rural Development, 15(3), 12401246.

Oakley, A. (1985). Sex, Gender and Society. London: Temple Smith.

Obafemi. 0. (2002). Making a difference through theatre in a democracy. In Yekima, A. \& Akinwale, A. (Eds.), Theatre and Democracy in Nigeria. Ibadan: Kraft.

Okoh, J. (2000). Edewede. Owerri: Totan.

Onwueme, T. O. (2002). Then She Said It. Lagos: African Heritage Press.

Oyedepo, S. (2000). My Daughter is an Egg. Ilorin: Delstar.

Oyedepo, S. (2002). The Rebellion of the Bumpy-Chested. Ilorin: Delstar.

Salami-Agunloye, I. (2006). Emerging trends from the shadows? changing patterns

in Edo women's political participation. Women, Theatre and Politics: A Contemporary Perspective. Ibadan: Saniez, pp. 89-106.

Tyson, L. (2011). Using Critical Theory: How to Read and Write about Literature. 2nd ed. Oxon: Routledge.

Uko, I. (2004) Gender and Identity in the Works of Osonye Tess Onwueme. Trenton, New Jersey: Africa World Press.

\section{Contact}

Rowland Chukwuemeka Amaefula Alex Ekwueme Federal University Ndufu-Alike, Ikwo, Nigeria emy4real2004@gmail.com 